\title{
Failure analysis and repair of the telescopic beam belonging to the spreader of a reach stacker for port operations
}

\author{
Análisis de falla y reparación de la viga telescópica perteneciente al spreader de un \\ equipo móvil terrestre para operaciones portuarias
}

\author{
F.A. Bermejo-Altamar (iD); E. Buelvas-Castro iD; R.A. Mendoza-Quiroga iD
}

\begin{abstract}
Reach stackers land equipment operating in ports of the Colombian Caribbean, are subject to several critical working conditions such as; corrosive environment, excess working hours, overload and lack of predictive maintenance. This work focuses on the failure analysis and the elaboration of the welding repair procedure of the telescopic beam belonging to the spreader of a Reach stacker that operates in a Colombian Caribbean seaport. Initially the fault zone was characterized; by mean a metallographic analysis and a hardness profile to identify the type of structural steel of which the beam is composed, obtaining an A514 grade $C$ of 110KSI of tensile strength and 34HRC of hardness. The equipment manufacturer was verified and the established by the laboratory tests was corroborated. After identifying the material, the fracture area was analyzed where patterns of beach markings were found, typical of a fatigue failure which extended from the circumference of separating pins to the surface of the beam. The inclusion of the separators in the initial design generates stress concentrators in the welding of the pins which increases the fatigue zone combined with the excess load with which the equipment works. This fact could be verified with a technical bulletin published by the manufacturer brand "Taylor" where it indicates this type of failure for the telescopic beam of the Reach stackers. Successively, an FCAW type welding repair procedure is developed in accordance with AWS code D1.1, where the electrode to be used, the cords to be applied, the preheating, and the speeds and conditions recommended for filling the materials are selected cracks. Finally it could be concluded that the fault was generated by fatigue and overload in the welding of the telescopic beam separator pins and its repair will be carried out according to a welding procedure of the AWS code D1.1. The analysis of these types of cases will allow the company to take actions to minimize the new occurrence of the failure such as periodic reviews in that area after the work hours recommended by the manufacturer and the awareness of the equipment operators with the handling of loads on the dock.
\end{abstract}

Index Terms - Failure Analysis; fatigue; crack; beam; welding procedure.

Resumen-Los equipos apiladores de tierra que operan en los puertos del Caribe colombiano están sujetos a varias condiciones

This manuscript was sent on November 08, 2019 and accepted on March 14, 2020. This work was supported in part by GI FOURIER of Universidad Antonio Nariño (Puerto Colombia, Colombia).

F. A. Bermejo-Altamar is professor in the Mechanical Engineering Program (GI-FOURIER research group) at Universidad Antonio Nariño (Puerto Colombia, Colombia) (e-mail: fbermejo@uan.edu.co). de trabajo críticas como son: ambiente corrosivo, exceso de horas de trabajo, sobrecarga y falta de mantenimiento predictivo. Este trabajo se enfoca en el análisis de fallas y la elaboración del procedimiento de reparación de soldadura de la viga telescópica perteneciente al separador de un apilador Reach que opera en un puerto caribe colombiano. Inicialmente se caracterizó la zona de falla; mediante un análisis metalográfico y un perfil de dureza para identificar el tipo de acero estructural del que está compuesta la viga, obteniendo un grado $\mathrm{A514} \mathrm{C}$ de 110KSI de resistencia a la tracción y 34HRC de dureza. El fabricante del equipo fue verificado y lo establecido por las pruebas de laboratorio fue corroborado. Después de identificar el material, se analizó el área de fractura donde se encontraron patrones de marcas de playa, típicos de una falla por fatiga que se extiende desde la circunferencia de los pasadores de separación hasta la superficie de la viga. La inclusión de los separadores en el diseño inicial genera concentradores de esfuerzos en la soldadura de los pasadores, lo que aumenta la zona de fatiga combinada con el exceso de carga con la que trabaja el equipo. Este hecho podría verificarse con un boletín técnico publicado por la marca del fabricante "Taylor", donde indica este tipo de falla para el haz telescópico de los apiladores Reach. Luego, se desarrolla un procedimiento de reparación de soldadura tipo FCAW de acuerdo con el código AWS D1.1, donde el electrodo que se utiliza, los cables que se aplicaran, el precalentamiento, las velocidades y condiciones recomendadas para llenar los materiales sobre grietas seleccionadas. Finalmente, se pudo concluir que la falla fue generada por fatiga y sobrecarga en la soldadura de los pasadores del separador de haz telescópico y su reparación se realiza de acuerdo con un procedimiento de soldadura del código AWS D1.1. El análisis de este tipo de casos permitirá a la compañía tomar medidas para minimizar la nueva ocurrencia de la falla, como revisiones periódicas en esa área después de las horas de trabajo recomendadas por el fabricante y la conciencia de los operadores del equipo con el manejo de cargas en el puerto.

Palabras claves - Análisis de fallas; fatiga; grietas; vigas; procedimientos de soldadura.

\section{INTRODUCTION}

$\mathrm{T}$ HIS work is a case study about failure analysis in a telescopic beam of a reach stacker, where is studied the

E. Buelvas-Castro is professor in the Mechanical Engineering Program (GIFOURIER research group) at Universidad Antonio Nariño (Puerto Colombia, Colombia) (e-mail: edgardo.buelvas@uan.edu.co).

R. A. Mendoza-Quiroga is professor in the Mechanical Engineering Program (GI-FOURIER research group) at Universidad Antonio Nariño (Puerto Colombia, Colombia) (e-mail: rimendoza@uan.edu.co). 
mechanism of failure and the welding procedure repair.

The shutdown of such equipment represents high losses for the port companies since it does not exist due to the high cost of standby replacements that may occupy their operational place. Material fatigue refers to a phenomenon whereby the breakage of materials under dynamic cyclic loads occurs more easily than with static loads [1].

This failure type has been studied in structures and pipelines, however recently jobs focuses in the study of growing cracks, stress corrosion cracking and fracture mechanical.

Wang et al [2] analyzed the mechanical behavior of crack growth under stress-assisted corrosion in an X80 underground steel pipe, under the action of a wet and acid soil. The gradual spread of the crack changed from ductile to fragile. The crack growth rate accelerated significantly with a decrease in the $\mathrm{pH}$ solution.

TK Christman et al [3], conducted a study on steel pipe lines, where it presents relationships between pitting, stress and stress-assisted corrosion, these interactions occur because cracks are generally generated from a pit whose depth follows a normal logarithmic distribution. A mathematical analysis of the number of cracks and the depth of the sting supports the hypothesis that the crack nuclei from the bottom of the sting when the concentration of effort in that area reaches a critical value.

Sharma et al [4] studied stress corrosion for an ultra-fine grain in an $\mathrm{Al}-7.5 \mathrm{Mg}$ alloy and a conventional $5083 \mathrm{H} 111$ alloy in natural seawater and at low deformation rates. The authors found a low sensitivity to the strain rate for both alloys.

Intergranular attack and stress-assisted corrosion on 600 Inconel alloys was studied by Thomas et al [5], who found that intergranular attack and cracking followed local or oxidation dissolution and pore formation at grain boundaries. This degradation occurred on a nanometric scale and therefore required high resolution methods (ATEM Analytical Transmission Electron Microscopy) to reveal the characteristics in detail.

Sánchez et al [6], studied the arrest of cracks in stress-assisted corrosion by means of propagation velocity tests on highstrength steels. The electrochemical response was studied from the beginning of the crack to its growth and the effects of its propagation were evaluated through mechanical parameters.

Zuo et al [7] studied the effect of stress on cracking speed and the critical $\mathrm{pH}$ value within stress-assisted corrosion, who found that the corrosion rate (SCC) was higher in magnitude than the corrosion rate of the samples tested by stress, this indicates that the mechanical failure induced by hydrogen embrittlement is the dominant factor in the stress-assisted corrosion rate (SCC). Eto et al [8] analyzed the effect of residual stresses induced by pulsed laser irradiation on the initiation of stress-assisted corrosion in a stainless steel under the action of chlorides. The results showed that laser irradiation is less effective in obtaining the residual stresses of the sample compared to irradiation by laser pulses in the sample treated by shot blasting. The depth of the tension obtained by laser irradiation is much less than that of the compression effort obtained by shot blasting.

This type of corrosion also occurs in the industry, Abdullah et al [9] analyzed the SCC, the prediction in the growth of cracks and the risk-based inspection in ammonia tanks for industrial refrigeration. A new model was generated in this study, the results of which are consistent with those found in the literature and practical experiences. To complement this, a global evaluation was carried out through the risk-based inspection of a typical fertilizer plant, where the consequences of the tank failure were found to be high, but the overall risk is still manageable.

\section{METODOLOGY}

Methodology implemented for the execution of the research was the following:

- Failure detection in situ

- Sample collection and laboratory studies

- Failure Analysis and welding procedure

- Conclusions

\section{A. Failure detection in situ}

Taking the refrigerated container off the floor when lifting it, the spreader extension was split on the right side (Fig 1).

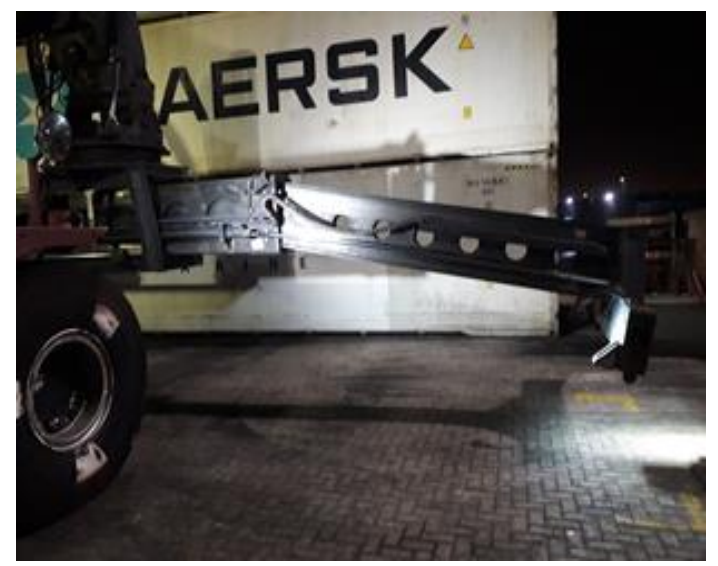

Fig 1. Fractured Telescopic Beam.

After to analyze the failure zone is taken the following evidence:

- The fracture occurs in the spreader telescopic system beam when the spreader is in the 40-foot position (Fig 2).

- The fracture begins within the tunnel of the telescopic system ( 2 inches measured from the outer edge).

- It is evident that the fracture area is not visible when the spreader is open at 40 feet which prevents seeing any defect in the material.

- Cylindrical elements welded along the fracture

- The fissure is presented at 2 inches measured from the edge of the frame (Fig 3). 


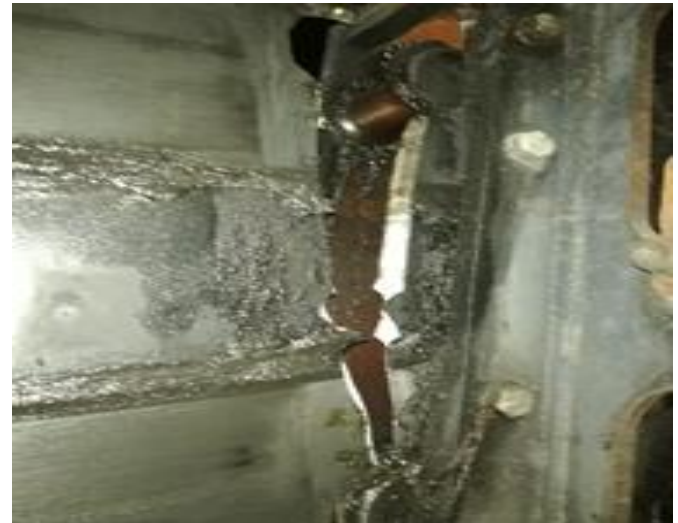

Fig 2. Fractured area.

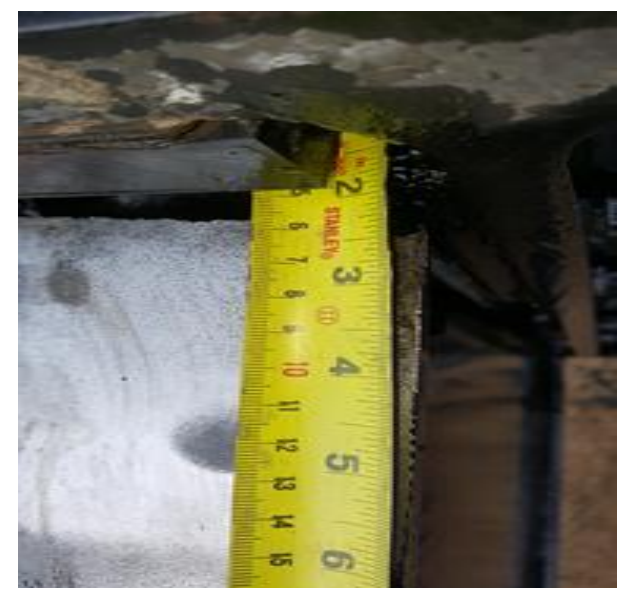

Fig 3. Fissure Length since pin separator to frame.

\section{B. Sample collection and laboratory studies}

\section{Equipment}

\section{Bench hardness tester}

The different versions of the zwick ZHU 187.5 universal durometer cover the test loads between $29.4 \mathrm{~N}$ and $1839 \mathrm{~N}$, and are designed for testing according to Vickers, Brinell and Rockwell.

\section{Metallography equipment}

Metallography equipment used for the sample analysis is composed of:

- Sandpaper kit

- Polisher

- Assembly bench

- Optical microscopic

The material was characterized in the laboratory to know its composition and mechanical properties through hardness tests and metallographic analysis. The results obtained are presented below.
After calibrating the Bench hardness tester, the hardness profile was measured on the upper faces and bottom of the sample as seen in Fig. 4. Three points were measured on each face longitudinal and then the average was taken as established by ASTM E10.

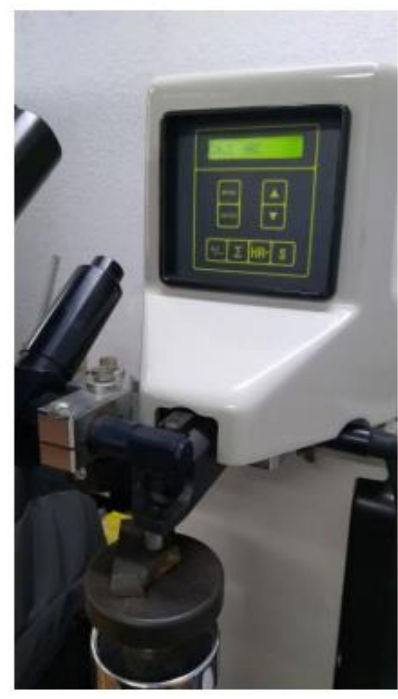

Fig 4. Hardness measure on bench.

After taking the measures, the chemical composition and mechanical properties are showed in table I. Hardness profile in upper and bottom side are presented in table II.

TABLE I

CHEMICAL COMPOSITION AND MECHANICAL PROPERTIES

\begin{tabular}{cccccc}
\hline \hline \multirow{2}{*}{ Grade } & \multicolumn{5}{c}{ Chemical composition } \\
\hline & $\mathrm{C}$ & $\mathrm{Mn}>$ & $\mathrm{Si}$ & $\mathrm{P}$ & $\mathrm{S}$ \\
\cline { 2 - 6 } & 0,26 & $0,4-0,9$ & 0,4 & 0,04 & 0,05 \\
\cline { 2 - 6 } ASTM & \multicolumn{5}{c}{ Mechanical properties } \\
514 & $\mathrm{Sut}$ & $\mathrm{Sy}$ & $\%$ & Affect & Hardness \\
& $(\mathrm{MPa})$ & $(\mathrm{Mpa})$ & Ductility & $\begin{array}{c}\text { Temperature } \\
\text { test }\end{array}$ & $($ HB) \\
& & & & test & $300-320$ \\
\hline \hline
\end{tabular}

Source [10]; http://www.steel-grade-plate.com/carbon-and-low-alloy-high-strength-steelplate/astm-a514-a514m/astm-a514-grade-a-a514gra-carbon-and-low-all.html

TABLE II

HARDNESS PROFILE

\begin{tabular}{lcccc}
\hline \hline Side & \multicolumn{3}{c}{ Hardness (HRC) } & Average (HRC) \\
\hline Upper & 35.8 & 33.1 & 32 & 33.6 \\
Bottom & 34.8 & 34.2 & 35.8 & 34.9 \\
\hline \hline
\end{tabular}

According to this measurement and the information sent by the company, it was verified that corresponds to a structural steel A514, which consulting with steel suppliers. It has hardness between 235 and 293 Brinell. Hardness approaches the upper limit of convert the scale from Rockwell C to Brinell in 311.

\section{Metallography}

The following metallography taken at $200 \mathrm{X}$ was obtained by metallographic analysis (Fig 5). 


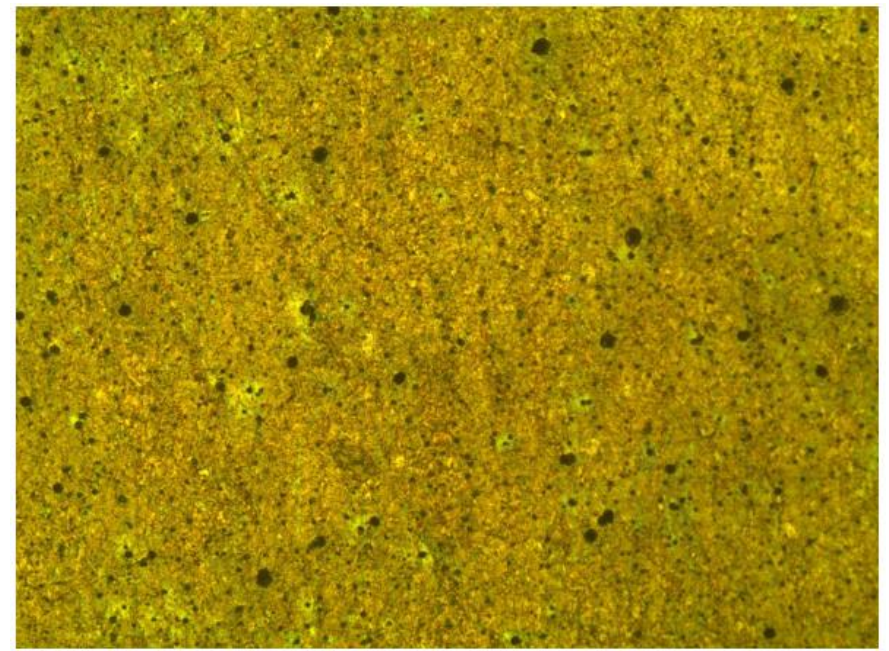

Fig 5. Metallographic taken at 200X.

Photomicrograph Fig. 5 shows a typical microstructure of low carbon steel, in where perlite (dark areas) precipitated on the grain edges of a matrix is observed ferritic (clear areas). Metallographic analysis corroborates the hardness measurement, relating the sample to A514 steel, which has a carbon content of $0.26 \%$. Table II shows the composition and the main mechanical properties of this do according to a provider.

\section{FAILURE ANALYSIS AND WELDING PROCEDURE}

After disassembling the billed arm, the left arm was dismantled and penetrating ink tests were performed. On both sides of the beam cracks are evident around the spacer pins (Fig 6).
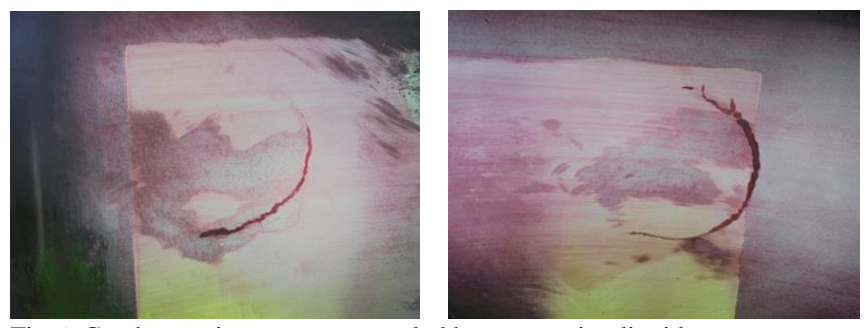

Fig 6. Cracks on pin separator revealed by penetrating liquids

\section{A. Fracture characterization}

Macroscale fractographic characteristics:

- The type of material used in the construction of Spreader is a T-1 alloy (registered trademark of the ArcelorMittal steel company) equivalent to A514 steel

- Mechanical properties of A514 steel; creep limit at least $100 \mathrm{ksi}(689 \mathrm{MPa})$ for thicknesses up to $2.5 \mathrm{in}$ $(63.5 \mathrm{~mm})$

- Breaking tension at least $110 \mathrm{ksi}(758 \mathrm{MPa})$, with a specific range of 110-130 ksi (758 - $898 \mathrm{MPa})$

- Discontinuities, porosity, lack of fusion and cracks in the weld are evident between the cylindrical separator and the base material sheet, like shows Fig. 7.
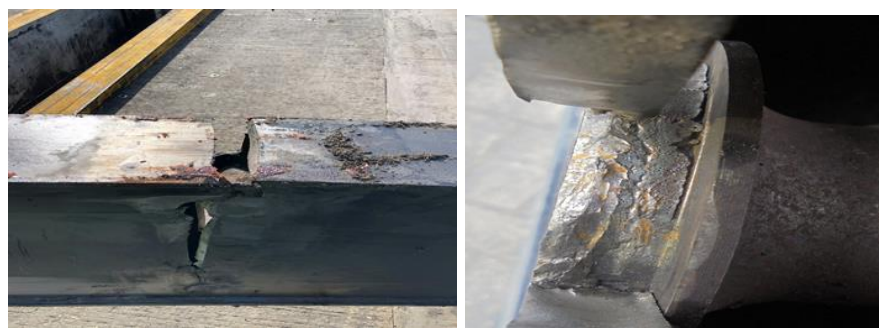

Fig 7. Welding between cylindrical separator and sheet.

The surface of the blade fracture has beach marks and rapid fracture. Since beach marks spread away from the origin in a series of concentric arches, the site from which the crack originated can be identified by drawing an imaginary radius perpendicular to them" [11]. Therefore, it can be inferred that the fracture originated at the limit between the sheet and the cylindrical separator.

The failure could have been caused by fatigue, the most likely root cause being an inappropriate choice of the type of welded joint used, that is, a poor design. This design is not recommended for dynamic structures.

Sudden fatigue fracture failure is evidenced being nucleated in welding imperfections between the separator pin and the base material sheet. These fatigue cracks that originated in welding could not have been detected during routine inspections since these cylindrical separators are not visible as they are within the central frame of the spreader. Therefore, it should be noted that there is no deficiency in the inspection work (Fig 8).

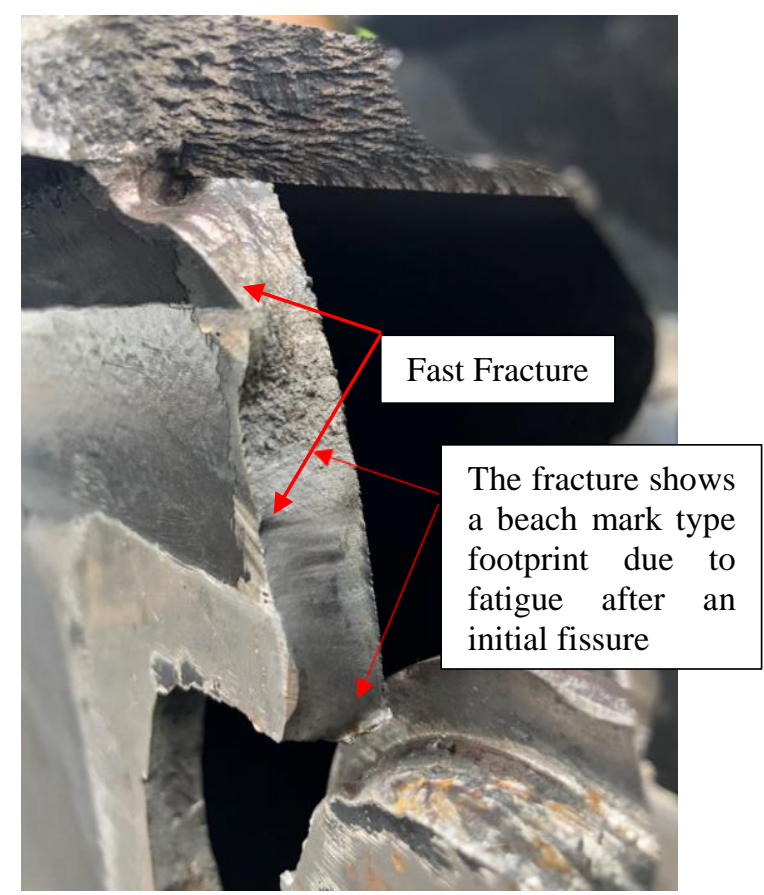

Fig 8. Fracture surface of the base material sheet, fractography analysis. 


\section{B. RCA (Root cause Analysis) Development}

Problem identified:

Equipment stops due to loss of the lifting function due to damage to the Spreader structure.

Immediate cause

- Fracture in the telescope structure right side of the spreader

Basic causes

- Structural failure due to fatigue in the telescopic beam of the spreader.

- Efforts are greater than the load capacity of the machine (45 Ton).

- Due to lack of knowledge, the current Structural Predictive Maintenance procedure in this equipment does not include inspections in the area where the fracture originated.

- Failure due to defective material.

- Improper design to support the combined loads.

Validation of possible basic causes

- Cause "Structural failure due to fatigue in the telescopic beam of the spreader". According to the analysis by fractography if there was fatigue that gave rise to a crack in the vicinity of the separator pins.

- Cause "There are efforts greater than the load capacity of the machine (45 Ton)". There is no evidence of overload; however, there is knowledge of improper operations of the equipment.

- Cause "The current Structural Predictive Maintenance Procedure USED BY THE TECHNICAL AREA of company is this equipment does not include inspections in the area where the fracture originated". The area where the fracture occurred is a hidden area that is not visible with the Spreader open at 40 feet, and inspections do not contemplate hidden areas.

- Cause "Failure due to defective material". Discontinuities were evidenced by lack of fusion and welding porosity between the separator pin and the beams; Evidence of the fracture around the separator pin

- Cause "Improper design to withstand combined loads." According to the "Service Bulletin" report published by Taylor Sudden Service on August 6, 2013, it recognizes that this equipment has been damaged after one year of use and the Technical area was not aware of the potential failures in the unit.

\section{Root Causes}

The root cause that led to the loss of the lifting function of the equipment is a fatigue in the structure due to a deficiency in the structural design of the Spreader, and the service bulletin "Service Bulletin Vol. 13 / Number 4 / August 6, 2013 being made known late. "This explains the problems that had arisen with these equipments in that area and where they should be inspected. Because of this, preventive actions could not be taken in a timely manner. Root cause analysis is shown in the Fig. 9.
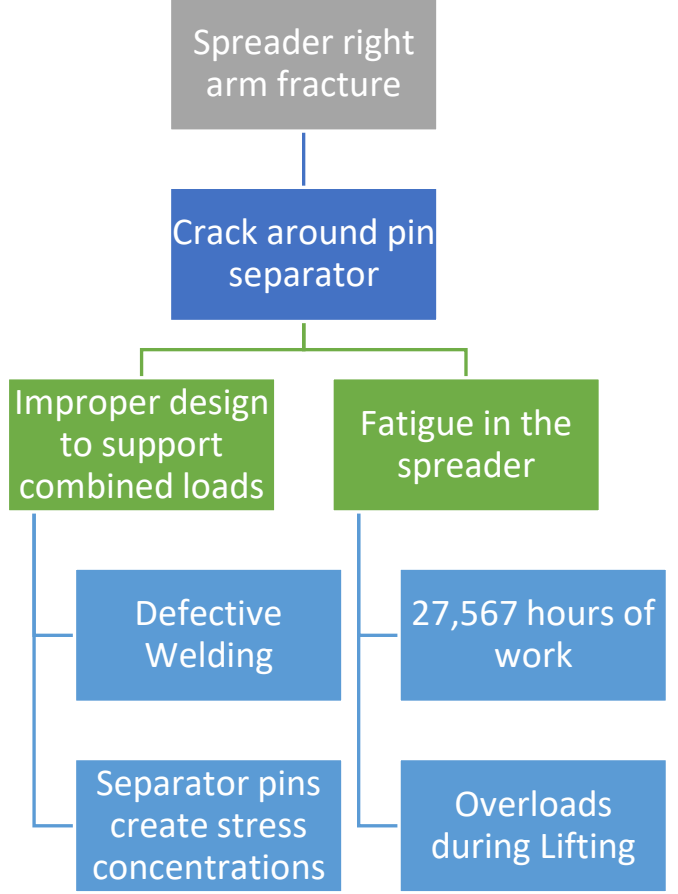

Fig 9. Schematic block of RCA

\section{Welding Procedure for the repair}

Welding procedure was elaborated with the code AWS D1.1 2015. Mainly parameters of welding procedure are shown in table III.

TABLE III

MAINLY PARAMETERS OF WELDING PROCEDURE

\begin{tabular}{ccccc}
\hline \hline Pass & Process & $\begin{array}{c}\text { Current } \\
\text { Type - Amp }\end{array}$ & Voltage & Speed forward \\
\hline 1 & FCAW & DCEP 219-260 & $25-30$ & $150-160 \mathrm{~mm} / \mathrm{min}$ \\
\hline 2 & FCAW & DCEP 270-330 & $25-35$ & $280 \mathrm{~mm} / \mathrm{min}$ \\
\hline $3-\mathrm{N}$ & FCAW & DCEP 200-291 & $25-35$ & $280-400 \mathrm{~mm} / \mathrm{min}$ \\
\hline \hline
\end{tabular}

Following items show important aspects of procedure

- Welding Procedure; FCAW (Flux-cored arc welding)

- Type; Semiautomatic.

- Joint Design; Total penetration, root open 1/8", bevel angle $60^{\circ}$, Heel $1 / 8^{\prime \prime}$.

- Welding Position; 2G, Butt joint.

- Base material; A514 grade C, thickness $12.5 \mathrm{~mm}$, Butt joint.

- Electrical Characteristic; Transfer mode "Pressed", Direct current, polarity "DCEP Positive Wire", 
Voltage 20-35V.

- Filler material; Electrode E 110 T5-K4, specification.

- AWS A5.29, diameter $1.6 \mathrm{~mm}$, commercial provider; Bohler/WestArco/Lincoln.

- Technique; cord swung, Multiple passed, Longitudinal, Cleaning between passes "Polisher, metallic grata.

- Protection; $\mathrm{CO}_{2}$ gas, $100 \%$ composition, flow 20Lts/min.

- Preheating; Min Temperature $200^{\circ} \mathrm{C}$, temperature between passes $\operatorname{Min} 155^{\circ} \mathrm{C}-\operatorname{Max} 300^{\circ} \mathrm{C}$.

- Post welding thermal treatment: Cover with thermal blanket until room temperature.

- Joint detail:

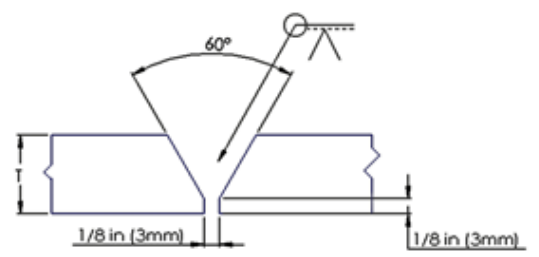

Fig. 10. Joint detail.

\section{CONCLUSIONS}

The development of this work allowed to know the root cause of a structural failure in the telescopic beam of the spreader of a ground equipment for port operations. These types of studies are carried out in these companies to establish, in addition to the causes of the failure, a general methodology that can be applied to the different equipment operating in the port. The daily life of the company does not allow the maintenance department to carry out this type of study, which in turn is hired by third parties.

The fault was generated by the combination of fatigue in the circumferential welding to some separator pins with the beam and an overload in the reach stacker, when trying to lift a refrigeration container. The inclusion of the separator pins generates a geometry change in the cross section of the beam which produces stress concentrators, to this is added the lack of predictive maintenance in the area that in turn caused the welding to deteriorate due to corrosion effects. This fact was noted in a technical report by the equipment supplier, where he recommends inspecting the welding of the separator pins every year or every 6000 hours periodically and performing visual inspection every (3) months, which was not seen in time by the company maintenance department.

Understanding the failure of this type of structures allows the company to take the technical corrections described above so that it does not happen again, in addition to training and sensitizing the personnel of the correct operation of this type of equipment and the negative consequences that it brings to the company stops.

\section{REFERENCES}

[1] Robert C. Juvinall, "Fundamentos de diseño para Ingeniería Mecánica". Ed. Limusa, 1996, pp. 237-238.

[2] X.Z. Wang, Z.Y. Liu, X. Ge, X.L. Zhan, C.W. Du, and X.G. Li (2014) "Growth Behavior of Stress Corrosion Cracks of X80 Pipeline Steel in Underground Water of Acidic Soil”. Corrosion: Vol. 70, No. 9, pp. 872879. 2014. DOI: 10.5006/1094.

[3] T. K. Christman. "Relationships Between Pitting, Stress, and Stress Corrosion Cracking of Line Pipe Steels". Corrosion: Vol. 46, No. 6, pp. 450-453. 1990. DOI: 10.5006/1.3585131.

[4] Mala M. Sharma, Josh D. Tomedi, Timothy J. Weigley. "Slow strain rate testing and stress $\mathrm{s}$ corrosion cracking of ultra-fine grained and conventional Al-Mg alloy". Elsevier Materials Science \& Engineering A619 pp. 35-46. 2014. DOI: DOI: 10.1016/j.msea.2014.09.062.

[5] L. E. Thomas and S. M. Bruemmer. "High-Resolution Characterization of Intergranular Attack and Stress Corrosion Cracking of Alloy 600 in High-Temperature Primary Water". Corrosion: Vol. 56, No. 6, pp. 572587. 2000. DOI: 10.5006/1.3280561.

[6] J. Sanchez, C. Andrade, and J. Fullea. "Reasons for Crack Arrest in Stress Corrosion Cracking Tests-Crack Propagation Rate in High-Strength Steels". Corrosion: Vol. 65, No. 6, pp. 368-375. 2009. DOI: 10.5006/1.3319142.

[7] J. Y. Zuo, B. X. Gu, and Y. P. Liu. "Effects of Stress on Cracking Velocity and Critical pH Value inside Stress Corrosion Cracks". Corrosion: Vol. 47, No. 1, pp. 47-55. 1991. DOI: 10.5006/1.3585219.

[8] Shuzo Eto, Yasufumi Miura, Junichi Tani, Takashi Fujii "Effect of residual stress induced by pulsed-laser irradiation on initiation of chloride stress corrosion cracking in stainless steel". Elsevier Materials Science \& Engineering A590 pp. 433-439. 2013. DOI: 10.1016/j.msea.2013.10.066.

[9] M.O. Abdullah, J. Zen, and M. Yusof. "Stress Corrosion Cracking, Crack Growth Prediction, and Risk-Based Inspection of Industrial Refrigerated Ammonia Tanks". Corrosion: Vol. 67, No. 4, pp. 461-472. 2011. DOI: 10.5006/1.3580565.

[10] Steel grade plate. [Online] Available: http://www.steel-gradeplate.com/carbon-and-low-alloy-high-strength-steel-plate/astm-a514a514m/astm-a514-grade-a514gra-carbon-and-low-all.html, Accessed on: September 15, 2019.

[11] ASM International, "ASM Handbook", vol. 12: Fractography, ASM International, Materials Park, OH 44073-0002, fig. 50, p. 175. Reprinted with permission from ASM International ${ }^{\circledR}$, www.asminternational.org.

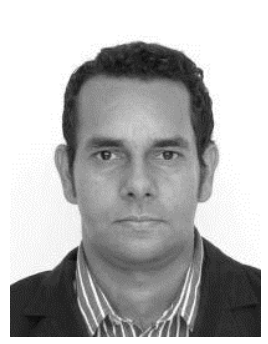

Fabio Andres Bermejo Altamar. Mechanical Engineer with a Master's degree in Mechanical Engineering, 7 years of experience in maintenance of Natural Gas, diesel and gasoline thermal engines, 13 years of academic experience (teaching, consultant, and research) and corrosion Technician of NACE international. He is an Assistant Professor at the Universidad

Antonio Nariño.

ORCID: https://orcid.org/0000-0003-1765-7802 


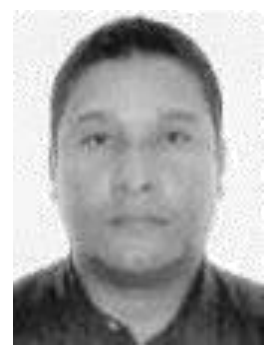

Edgardo M. Buelvas Castro was born in Santa Marta, Colombia. He graduated as a Systems Engineer from the Universidad del Norte, Barranquilla, in 1992, Master degrees in Computer Science from the Metropolitan University of Chile, Santiago, Chile, in 2011 and Doctor of Science and Technology from the Rafael Belloso Chacín University, Maracaibo,

Venezuela in 2015.

$\mathrm{He}$ is an Assistant Professor of the Systems Engineering program at the Universidad Antonio Nariño. His research interests are multidisciplinary in engineering such as modeling, applied mathematics, simulation, science, technology, and innovation. He belongs to several networks of researchers.

ORCID: https://orcid.org/0000-0002-3097-1997

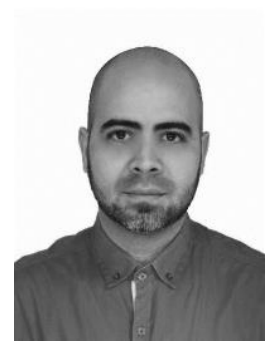

Ricardo Andrés Mendoza Quiroga was born in Barranquilla, Colombia. He received the B.S. degree in mechanical engineering from Universidad del Norte, Barranquilla, 2006 and M.S. in mechanical engineering degree from the Universidad de los Andes, Bogotá, 2010. He is an Assistant Professor of the Mechanical Engineering program at Universidad Antonio Nariño (Puerto Colombia, Colombia). Professor Mendoza research interest and courses are mainly related to Machine Design and Material Characterization.

ORCID: https://orcid.org/0000-0002-8040-5870 